\title{
Variations in soil properties and native woody plant species abundance under Prosopis juliflora invasion in Afar grazing lands, Ethiopia
}

Abeje Eshete ${ }^{1 *}$, Anna C. Treydte ${ }^{2,3,4}$, Mengsteab Hailemariam ${ }^{5}$, Negasi Solomon ${ }^{5}$, Tatek Dejene ${ }^{1}$, Zewdu Yilma ${ }^{1}$ and Emiru Birhane ${ }^{5}$

\begin{abstract}
Introduction: Pastoralism and agro-pastoralism are the major modes of life in arid and semi-arid rangelands. However, rangeland quality and quantity are rapidly deteriorating due to a number of natural and human-induced factors, one of which is bush encroachment. Little is known on how bush encroachment affects the ecosystem functions and services expressed in terms of the native vegetation composition and structure, status of the soil seed bank, soil chemical and physical properties, and the abundance of mycorrhiza spores.
\end{abstract}

Methods: We assessed woody species in 64 plots distributed across four levels of Prosopis juliflora invasion (high, medium, low, and none) at two sites, Amibara and Gewane, in the Afar Region, Ethiopia. We collected composite soil samples to investigate the soil seed bank, mycorrhizal associations, and spore abundance.

Results: Plant biodiversity was generally low, with eight and four woody species in Gewane and Amibara, respectively. Prosopis juliflora was dominant in highly, moderately, and lowly invaded areas while Acacia senegal dominated the non-invaded areas. The average number of $P$. juliflora individuals ranged from 3/ha at non-invaded areas in Gewane to 4200/ha at highly invaded areas in Amibara while the total individual number of native woody species ranged from 0 to $88 /$ ha at highly and lowly invaded areas, respectively. The population structure of trees/shrubs in all invasion areas showed an inverted J-shaped distribution, characterized by a high abundance of small individuals. Prosopis juliflora invasion was associated with high soil $\mathrm{OC}, \mathrm{Na}, \mathrm{Ca}$, $\mathrm{P}$, bulk density, and moisture content. Herbaceous seed numbers and species richness were highest in the moderately and highly invaded areas. All sampled tree species were associated with mycorrhiza but the percentage of root length colonization by different arbuscular mycorrhizal fungus structures varied significantly $(p<0.05)$ across invasion categories and sites.

Conclusions: Our results revealed that although $P$. juliflora invasion negatively impacted the availability of native woody livestock forage species, it had a positive effect on most soil physical and chemical properties. Such variable effects call out for sustainable management practices when invaded areas are restored.

Keywords: Encroachment, Structural and species diversity, Shrubs, Arbuscular mycorrhiza, Rangelands

\footnotetext{
* Correspondence: abejeye@gmail.com

${ }^{1}$ Central Ethiopia Environment and forestry Research Center (CEEFRC),

Ethiopian Environment and Forestry Research Institute (EEFRI), P.O. Box

30708, Addis Ababa, Ethiopia

Full list of author information is available at the end of the article
}

\section{Springer Open}

(c) The Author(s). 2020 Open Access This article is licensed under a Creative Commons Attribution 4.0 International License, which permits use, sharing, adaptation, distribution and reproduction in any medium or format, as long as you give appropriate credit to the original author(s) and the source, provide a link to the Creative Commons licence, and indicate if changes were made. The images or other third party material in this article are included in the article's Creative Commons licence, unless indicated otherwise in a credit line to the material. If material is not included in the article's Creative Commons licence and your intended use is not permitted by statutory regulation or exceeds the permitted use, you will need to obtain permission directly from the copyright holder. To view a copy of this licence, visit http://creativecommons.org/licenses/by/4.0/. 


\section{Introduction}

Drylands are areas where the potential amount of water that is transferred from land to atmosphere is at least 1.5 times greater than the mean precipitation (Davies et al. 2012). According to the Millennium Ecosystem Assessment (MEA (Millennium Ecosystem Assessment) 2005), drylands are defined as areas with an aridity index value of less than 0.65 , which means that annual precipitation is less than about two thirds of potential evapotranspiration. Such drylands cover more than $40 \%$ of the world's land area (UNCCD 2000), including shrubland, grassland, and forest (White and Nackoney 2003). Drylands are often regarded as being unproductive and barren, but they host over one third of the global human population, $90 \%$ of whom live in developing countries (MEA (Millennium Ecosystem Assessment) 2005).

Despite their aridity, drylands mainly support livestock while rain-fed agriculture is only practiced in small pockets (Ffolliott et al. 2002; Georgis 2005). Drylands contain a great variety of biodiversity (Redford et al. 1990), which is essential to the survival of species as well as to the livelihoods of people. This biodiversity plays a pivotal role in the global fight against poverty, climate change, and desertification (Smith et al. 2010). The majority of rural people living in drylands are pastoralists, semipastoralists, transhumant, and sedentary smallholders (Ffolliott et al. 2002). Pastoralism relies on a diversity of grasses and shrubs as key productive inputs (Blench 2001). However, pastoralism is challenged by a rapid decline in rangeland productivity caused by habitat conversion, climate change, over-harvesting, over-grazing, bush encroachment, and inappropriate soil management of rangelands (MEA (Millennium Ecosystem Assessment) 2005).

Bush encroachment is expressed as an excessive increase in the number of undesirable or unpalatable woody species that limit the growth of grasses and herbs palatable to livestock (Walker and Noy-Meir 1992; Ward 2005). The increase in bush ticket at the expense of perennial grasses is a commonly observed problem in dryland areas of the world (\Archer 2008; Eldridge et al. 2011) as it leads to degradation (Saco et al. 2007) due to low fire frequencies and invasive species proliferation (Pasiecznic et al. 2004). An increase in the abundance of encroachers suppresses the diversity, production, and productivity of forage plants and other multipurpose tree/shrub species with high food security importance in rangelands (Oba et al. 2000). Such species shifts are accompanied with fundamental alterations of habitat for animals (microbes, invertebrates, and vertebrates) and often result in a change of an ecosystem's trophic structure (Havstad et al. 2006). The rapid shift in species composition and abundance triggered by bush encroachment often enhances primary production, nutrient cycling, and accumulation of soil organic matter but can also have a negative effect on streamflow, groundwater recharge, livestock production, and biological diversity (Archer et al. 2001; Knapp et al. 2008). The increases in woody plant cover have become a major threat to pastoral livelihoods and ecosystems within the arid and semiarid areas (Eldridge and Soliveres 2015).

Rhizosphere microbial communities have been found to affect directly soil fertility by carrying out essential processes that contribute to nutrient cycling, soil structural maintenance, and ecosystem productivity (Smith and Read 2008). Among the most influential members of soil microbiota, mycorrhizal associations are the integral functioning parts of terrestrial ecosystems (Barea et al. 2011) and are widely recognized as providing a direct physical link between soil and plant roots (Smith and Read 2008). Arbuscular mycorrhiza fungi (AMF) is the predominant and ancestral type of mycorrhiza in land plants (Wang and Qui 2006). The interactions between plant-AMF link biodiversity and ecosystem functioning (van der Heijden and Sanders 2002). The AMF has a contribution on plant species composition and diversity, plant productivity, ecosystem functioning, and stability to environmental stresses and variables.

The Afar Region of Ethiopia has strongly been affected by bush encroachment due to the introduction of Prosopis juliflora in the late 1970s (EARO (Ethiopian Agricultural Research Organization) and HADRA (Henry Doubleday Research Association) 2005) and was first introduced for the purpose of rehabilitating degraded lands and for the provision of forest products like fuelwood and fodder for the pastoral community (Pasiecznik et al. 2001). However, P. juliflora has invaded large areas of grasslands, rangelands, water points, and croplands (Mekuyie et al. 2015) owing to its wide ecological adaptability (Pasiecznic et al. 2004), fast growth habit (Manchester and Bullock 2000), and high competition ability for available soil and water (Oba et al. 2000). The spread of $P$. juliflora in the Afar Region has an impact on ecology (Birhane et al. 2017; Ilukor et al. 2016), socioeconomics (Mehari 2015), and culture (Rogers et al. 2017) of the local people. However, little is known about the various levels of invasion by $P$. juliflora and its impact on the diversity and abundance of functional groups and different ecosystem services within invaded rangelands. Barbosa da Silva et al. (2016) and Pittarello et al. (2016) showed the negative effect of bush encroachment on the diversity and abundance of grasses and livestock forage provision. In contrast, Maestre et al. (2016) argued that bush encroachment could also have positive effects on certain biota and their associated functions and services in rangelands. While Soliveres et al. (2014) and Eldridge and 
Soliveres (2015) indicated that plant diversity and multiple ecosystem functions are maximized under moderate levels of bush encroachment, it is not yet clear how the different levels of $P$. juliflora invasion density affect plant diversity and ecosystem functions in Ethiopia. Assessing the effect of P. juliflora on plant diversity and other ecosystem functions is crucial to plan control methods that can minimize this species' impact and provide crucial inputs for policy and strategy formulations in Ethiopia. In this context, the main objectives of this study were to determine the native woody plant species diversity, structure and density, soil seed bank of native plants, soil nutrient availability, and soil mycorrhizal associations and spore abundance across the various levels of $P$. juliflora invasion in the Afar Region, Ethiopia. The main research questions were (i) how do the abundance, structure, and diversity of native woody species vary across the habitats that differ in the levels of $P$. juliflora invasion? and (ii) how do soil seed banks of native plants, soil nutrient availability, and soil mycorrhizal associations and spore abundance vary across the various levels of P. juliflora invasion? We hypothesized that the abundance and species richness of native woody species would be higher in the low invasion level while the diversity of native plant species in the soil seed bank, the availability of soil nutrients, mycorrhizal associations, and spore abundance would be higher at a high invasion level.

\section{Materials and methods}

\section{Study area}

The study was conducted in the Afar Region, eastern Ethiopia (Fig. 1). Afar is located in dryland areas of the country that cover more than $70 \%$ of the total landmass (Tamire 1997). These drylands have only a marginal potential for rain-fed agriculture but are highly suited for livestock husbandry (Hawando 1997), with 90\% of the local population being pastoralists and agro-pastoralists (Dalle et al. 2005). Acacia-Commiphora woodland is the dominant vegetation in the Afar Region (Eshete et al. 2005). This vegetation provides a multitude of benefits to pastoralists and agro-pastoralists like forage/feed, food, herbal medicine, timber, or firewood (Ilukor et al. 2016; Worku et al. 2011). The Acacia-Commiphora woodland in the Afar Region is strongly affected by $P$. juliflora (Birhane et al. 2017). Among the five zones of the Afar Regional State, we investigated the impact of the different level of invasion in two districts, namely Amibara and Gewane, located in Zone 3. The site characteristics, climate, and vegetation of the study districts are described by Birhane et al. (2017). Most of the land had been used for pastoralism while only little of the area is covered by agriculture (Kotu 2009).

\section{Study design and layout}

Both study sites were categorized into four levels of invasion based on the P. juliflora cover percentages which were estimated visually (Birhane et al. 2017): no P. juliflora present ("none"; P. juliflora cover $<3 \%$ ), low cover

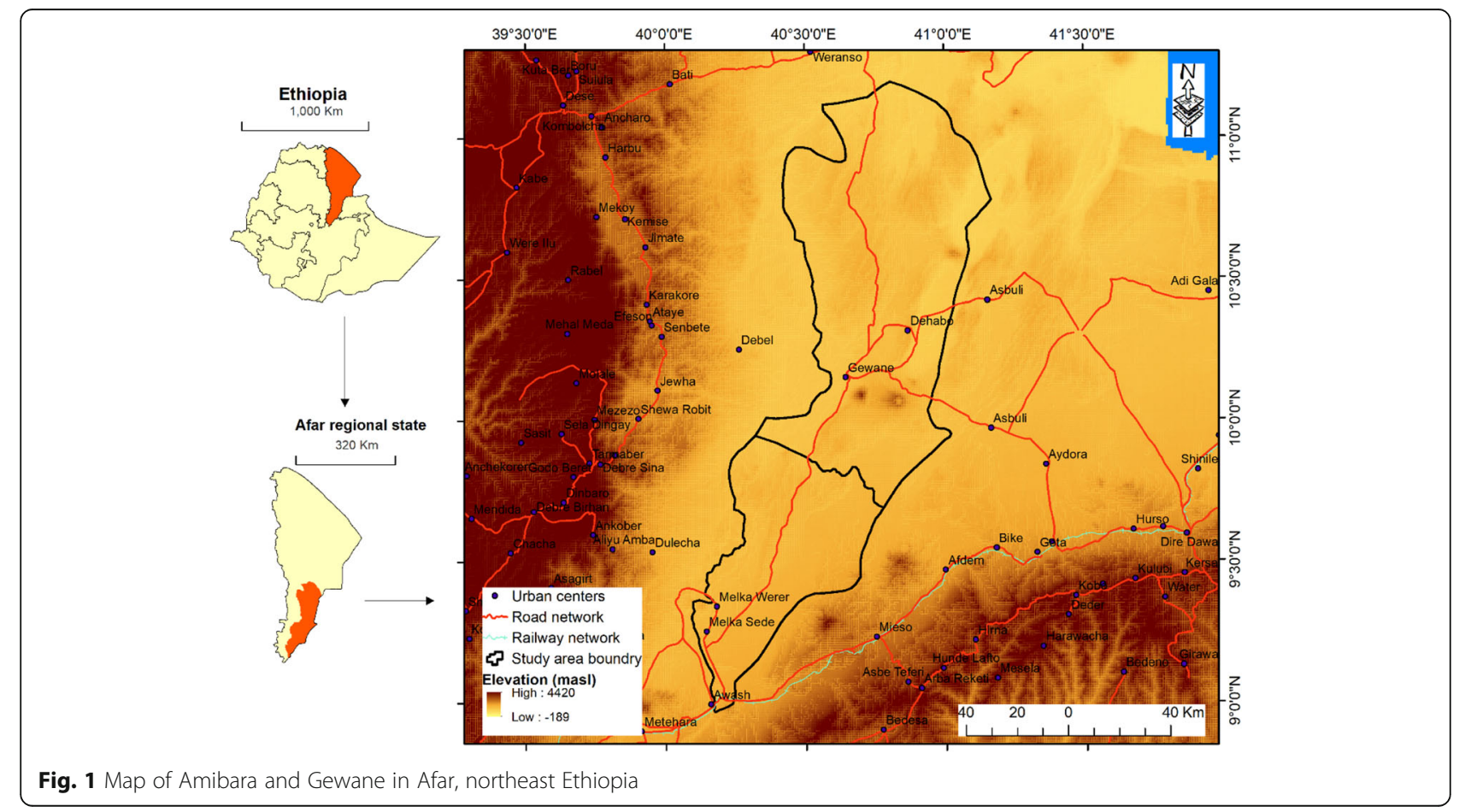


("low"; P. juliflora cover 3-40\%), intermediate cover ("med"; P. juliflora cover 40-60\%), and high cover ("high"; P. juliflora cover > 60\%, Fig. 2). The invasion rate of $P$. juliflora decreased with distance away from the road. In each of the studied districts, eight transects of $1000 \mathrm{~m}$ length were laid out perpendicular to the road at a distance of $1500 \mathrm{~m}$ apart from each other using a systematic random sampling technique. All transects crossed the four invasion rates (Fig. 2). A total of 64 plots (16 plots in each of the 4 invasion levels) were laid out along each transect at every $200 \mathrm{~m}$. A plot size of 20 $\times 20 \mathrm{~m}\left(400 \mathrm{~m}^{2}\right)$ was employed for the three levels of invasion: none, low, and medium, while a plot size of $5 \times$ $5 \mathrm{~m}\left(25 \mathrm{~m}^{2}\right)$ was employed for the high invasion level due to logistical reasons.

\section{Vegetation inventory}

In each plot, all tree and shrub species $\geq 1.5 \mathrm{~m}$ height were identified and measured for their root collar diameter (RCD) $(\mathrm{cm})$ and their stem height (in $\mathrm{m}$ : to the top of the crown) using a height measuring graduated pole. All trees/shrubs $\geq 0.5 \mathrm{~m}$ and $\leq 1.5 \mathrm{~m}$ height were also systematically identified and counted. Local names of trees/shrubs were recorded and identified to the species level according to different volumes of the flora of Ethiopia (Hedberg 1996), with the help of locals and through comparisons with voucher specimens from the National Herbarium at Addis Ababa University.

\section{Soil seed bank sampling}

Soil samples were collected from five small sub-plots of $40 \times 40 \mathrm{~cm}\left(1600 \mathrm{~cm}^{2}\right)$ and $30 \mathrm{~cm}$ deep at plots used to measure the diameter and height of woody plants, one at the center and the other four at the four corners. From each sub-plot, three successive soil layers $(0-10 \mathrm{~cm}, 10-$ $20 \mathrm{~cm}, 20-30 \mathrm{~cm}$ ) were collected using a sharp knife. Soils from similar layers were mixed to form soil composites in order to reduce variability within the plot and divided into five equal parts, one of which was selected randomly as a representative soil sample (Mengistu 2001). The soil samples were transported to Mekelle University for soil seed bank analyses. A total of 192 pots filled with $1 \mathrm{~kg}$ soil sample were placed at random in the greenhouse and were hand-watered regularly until saturation. Pots were then examined to record data on the emergence of plants every 3 days for the first 2 months and thereafter weekly until the end of the experiment, i.e., for 6 months. Seedlings that started to emerge and were readily identifiable were counted, recorded, and discarded. Those difficult to identify at the seedling stage were first counted but maintained in the pots until they were identified. After 6 months, the number of emerging seedlings, particularly grasses and forbs,
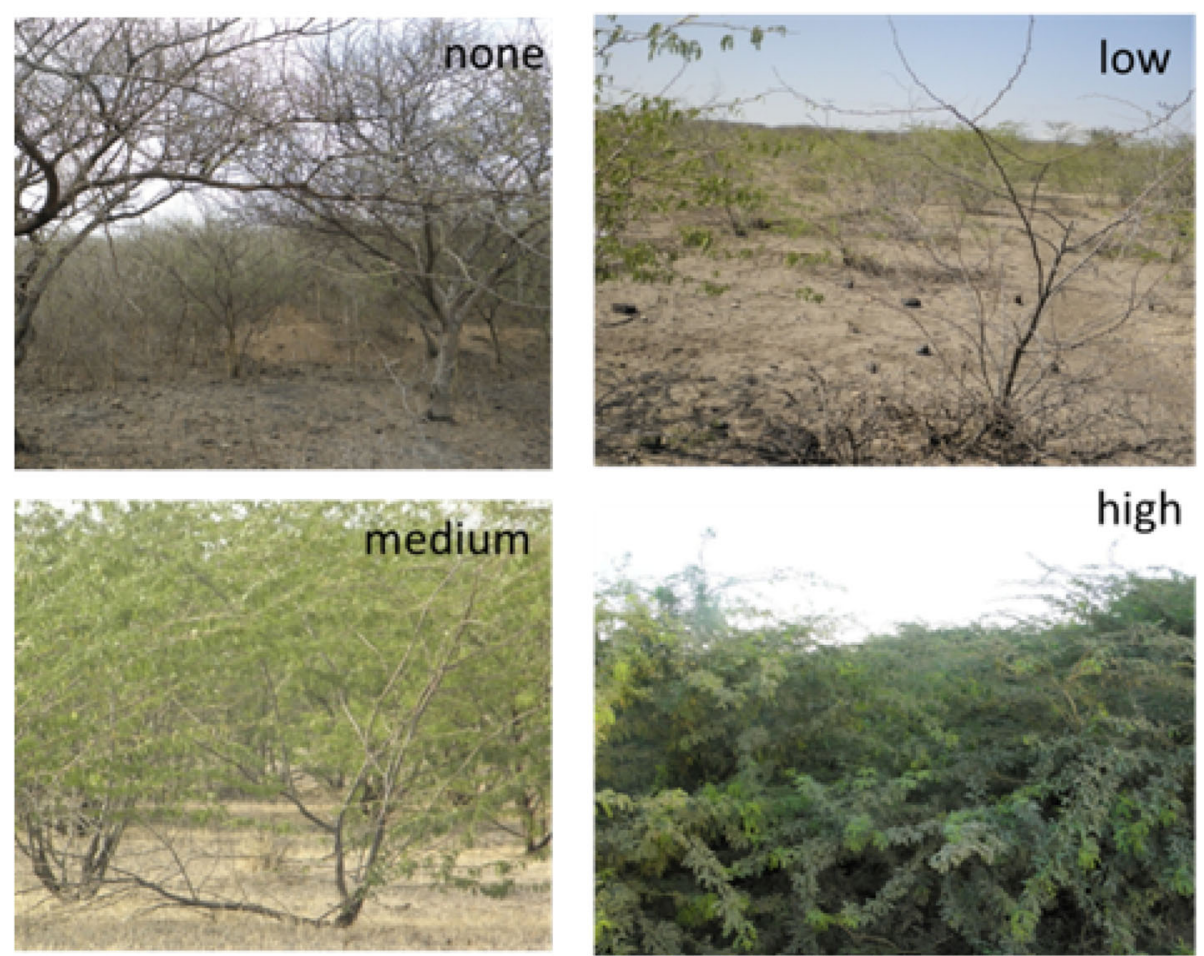

Fig. 2 The different invasion categories of $P$. juliflora in the two study sites. No P. juliflora individuals ("none"; $P$. juliflora cover $\leq 3 \%$ ), low cover ("low"; P. juliflora cover 3-40\%), intermediate cover ("med"; P. juliflora cover 40-60\%), and high cover ("high"; P. juliflora cover > 60\%) 
declined considerably. Plant nomenclature followed the flora of Ethiopia (Hedberg 1996).

\section{Collection of rhizosphere soil and root samples}

Samples for spore analyses were collected from the already established plots for vegetation study. Rhizosphere soil and roots were collected in the dry season (December). The surface soil of about $1-2 \mathrm{~cm}$ was removed, and soil cores of $0-30 \mathrm{~cm}$ collected including fine roots and rhizosphere soils of the host plants using a cylindrical soil corer of $10 \mathrm{~cm}$ internal diameter. From each sample plot, three individuals of each dominant plant species with similar crown width (about $1.5 \mathrm{~m}$ ) were randomly selected and samples were taken $50 \mathrm{~cm}$ away from the tree trunk in four compass directions. The four samples were mixed thoroughly to form a composite soil sample per each tree. Generally, two composite soil samples per species were taken from each plot. A total of 120 composite soil samples were collected. A sub-sample of approximately $100 \mathrm{~g}$ was taken for the extraction of arbuscular mycorrhizal fungus (AMF) spores. The soil samples were air-dried and passed through a 2-mm sieve, and then samples were stored at $4{ }^{\circ} \mathrm{C}$ before analysis. Alive fine roots were also collected from each plant for AMF colonization assessment. Roots were excised in the amount of about $1-5 \mathrm{~g}$ for each species and placed in a sealed plastic bag to protect from desiccation.

\section{Physical and chemical analyses of soil samples}

Selected physical and chemical properties were analyzed, such as available phosphorus $(\mathrm{P})$, total nitrogen $(\mathrm{N})$, organic carbon (OC), exchangeable sodium $(\mathrm{Na})$, exchangeable potassium (K), exchangeable calcium (Ca), exchangeable magnesium $(\mathrm{Mg})$, cation exchange capacity (CEC), bulk density (BD), moisture content (MC), and soil texture following standard soil analysis methods. OC was determined by the wet combustion procedure of Walkley-Black (Van Ranst et al. 1999) while N was determined by the wet-oxidation procedure of the Kjeldahl method (Bremner and Mulvaney 1982). Available P content was determined by the P-Olsen method (Olsen and Sommers 1982) while $\mathrm{Na}, \mathrm{K}, \mathrm{Ca}, \mathrm{Mg}$, and CEC were determined by the $1 \mathrm{M}$ ammonium acetate $(\mathrm{pH} 7)$ method according to the percolation tube procedure (Van Reeuwijk 1993). The effective CEC was calculated as the sum of exchangeable cations extracted by the ammonium acetate buffered at $\mathrm{pH} 7$ plus $1 \mathrm{M} \mathrm{KCl}$ extractable $\mathrm{Al}$. Bulk density was determined by the core method (Blake and Hartge 1986). Soil texture was determined using the hydrometer method (Gee and Bauder 1982).

\section{AMF fungal spore extraction}

Spores were extracted from $100 \mathrm{~g}$ of air-dried subsamples after wet sieving and decanting followed by flotation centrifugation in 50\% sucrose (Brundrett et al. 1994). The soil samples were suspended in water for $30 \mathrm{~s}$ and decanted over a series of sieves with 750, 250, 100, and $38 \mu \mathrm{m}$ mesh size. Soil material was recovered from each sieve, suspended in water, and centrifuged at 2000 revolutions per minute (RPM) for 5 min (Brundrett et al. 1994). After decanting the supernatant, each soil-spore mixture of the pellets was re-suspended in sucrose solution (50\%) and centrifuged for $1 \mathrm{~min}$ at $2000 \mathrm{rpm}$. The supernatant containing spores was filtered under vacuum on filter paper and then transferred into a round petri dish with gridlines of $1 \mathrm{~cm}^{2}$ and finally counted using a stereoscope microscope. For observation and identification of spore characters, spores were mounted on glass slides in polyvinyl alcohol-lactoglycerol (PVLG) and PVLG + Melzer's reagent and identified to the genus level using current taxonomic criteria (Brundrett et al. 1994) and information by INVAM (http://www. invam.caf.wvu.edu).

\section{Assessment of AM fungi colonization}

Collected sub-sample roots were chopped down into 1$\mathrm{cm}$-long segments. The chopped samples were treated with $10 \% \mathrm{KOH}$ and autoclaved at $121{ }^{\circ} \mathrm{C}$ for $15 \mathrm{~min}$. Dark pigmented roots were bleached with $10 \% \mathrm{H}_{2} \mathrm{O}_{2}$ for $10 \mathrm{~min}$ and acidified with $3 \% \mathrm{HCl}(\mathrm{v} / \mathrm{v})$ for $30 \mathrm{~min}$ at room temperature. Cleared roots were transferred into a staining solution of trypan blue $(0.05 \% \mathrm{w} / \mathrm{v})$ in lactoglycerol (1:1:1, lactic acid to glycerol to distilled water) and autoclaved at $121^{\circ} \mathrm{C}$ for $15 \mathrm{~min}$ (Brundrett et al. 1994). Afterwards, stained roots were left in a de-staining solution $(50 \%$ glycerol) to remove colorations from empty root cells. Finally, six randomly selected stained roots of all plant species from each replicate were prepared and examined at $\times 100-400$ magnification under a microscope for the presence of AM fungal structures (arbuscules, vesicles, and internal hyphae in the root cortex). The proportional root colonization by AMF was estimated using the magnified intersection method (Brundrett et al. 1994) with hairline reticule inserted into an eyepiece at $\times 400$ magnification power under a compound microscope. The percentage of root length colonization was calculated from 100 or more intersections for each root sample. At each intersection, there were six possible mutually exclusive outcomes (Brundrett et al. 1994).

\section{Data analysis}

The densities of $P$. juliflora and the other woody species were calculated based on the total number of individuals recorded across all plots. To determine the population 
structure of trees/shrub species as a whole, first, all individuals encountered in the plots were grouped into 5 root collar diameter classes: $1 \leq 5 \mathrm{~cm}, 2=5-10 \mathrm{~cm}, 3=$ $10-15 \mathrm{~cm}, 4=15-20 \mathrm{~cm}$, and $5 \geq 20 \mathrm{~cm}$. The MannWhitney $U$ test was applied to reveal the differences in the density of native woody species between two invasion rates while the differences between the four invasion rates were tested using Kruskal-Wallis analysis of variance (ANOVA) method, with a transgression probability of $p=5 \%$. Soil properties, AMF spore density, and soil seed bank difference between sites (Amibara and Gewane) and invasion rates were analyzed using two-way analysis of variance. Data on AMF and soil properties were log-transformed to conform to normal distribution. Pearson correlation test was used to analyze the AMF associations with soil properties along with invasion rates. All statistical analyses were conducted using SAS 9.0, and the level of significance was set at $\alpha=0.05$. Tukey HSD test was performed to separate means of soil properties, AMF spore density, and soil seed bank.

\section{Results}

\section{Species composition and stand structure}

A total of eight and four tree and shrub species were recorded in Gewane and Amibara sites, respectively. The high, medium, and low invaded areas at the two study sites were almost fully occupied by $P$. juliflora while the non-invaded areas were dominated by Acacia senegal (Table 1). Few individuals of Acacia mellifera and Dobera glabra were found to coexist with $P$. juliflora in medium and low invaded sites at Amibara while no native tree/shrub species coexisted in medium and highly invaded sites at Gewane. Few individuals of Balanites aegyptiaca, A. mellifera, Acacia tortilis, and D. glabra were found in the low invasion sites and at no invasion

Table 1 Density of observed woody species at different levels of $P$. juliflora invasion rates

\begin{tabular}{|c|c|c|c|c|c|c|c|c|}
\hline \multirow[t]{2}{*}{ Woody species } & \multicolumn{4}{|c|}{ Amibara } & \multicolumn{4}{|c|}{ Gewane } \\
\hline & High & Med & Low & None & High & Med & Low & None \\
\hline Acacia mellifera & 0 & 9 & 25 & 0 & 0 & 0 & 0 & 3 \\
\hline Acacia senegal & 0 & 0 & 0 & 928 & 0 & 0 & 0 & 216 \\
\hline Acacia seyal & 0 & 0 & 0 & 0 & 0 & 0 & 25 & 0 \\
\hline Acacia species & 0 & 0 & 0 & 0 & 0 & 0 & 50 & 0 \\
\hline Acacia tortilis & 0 & 0 & 0 & 0 & 0 & 0 & 0 & 3 \\
\hline Balanites aegyptiaca & 0 & 0 & 0 & 0 & 0 & 0 & 13 & 0 \\
\hline Dobera glabra & 50 & 22 & 3 & 0 & 0 & 0 & 0 & 3 \\
\hline Prosopis juliflora & 4200 & 503 & 325 & 44 & 3850 & 444 & 378 & 3 \\
\hline
\end{tabular}

("none"; P. juliflora cover $\leq 3 \%$ ), low cover ("low"; P. juliflora cover 3-40\%), intermediate cover ("med"; P. juliflora cover 40-60\%), and high cover ("high"; P. juliflora cover $>60 \%$ ) sites at Gewane (Table 1). The density (number of individuals/ha) of native woody species differed significantly between the four invasion rates at Gewane $\left(\chi^{2}\right.$ $=25.124, p=<0.001, \mathrm{df}=3)$ and Amibara $\left(\chi^{2}=\right.$ 15.042, $p=0.002, \mathrm{df}=3$ ). A Mann-Whitney test indicated that the density of native woody species at high invasion categories was significantly higher than at the other three invasion levels at both sites. There was no significant difference between the medium, low, and none invasion levels in the density of native woody species at both sites.

The RCD of $P$. juliflora ranged from 0.5 to $17 \mathrm{~cm}$ at Amibara and from 1 to $26 \mathrm{~cm}$ at Gewane. More than $86 \%$ and $90 \%$ of $P$. juliflora individuals had a RCD of $<$ $5 \mathrm{~cm}$ at Amibara and Gewane, respectively. The number of all individuals/ha at the two sites was 1190, 175, 13, 0.8 , and 0.4 at the $1 \mathrm{st}$, 2nd, 3rd, 4th, and 5th diameter classes, respectively. The overall population structure of trees/shrubs in all invasion areas showed an inverted Jshaped distribution, characterized by higher proportions of smaller individuals ( $R C D \leq 5 \mathrm{~cm}$ ) and a gradually decreasing number of individuals with increasing diameter classes thereafter.

\section{Soil properties along with invasion rates and sites}

Soil physical and chemical properties differed significantly across $P$. juliflora invasion rates $(F=7.79, p=$ 0.0019 , Table 2). Organic C, Na, Ca, P, BD, MC, and textural classes showed significant differences among the invasion categories and across Amibara and Gewane sites. The interaction of sites and $P$. juliflora invasion rates showed significant differences for $\mathrm{OC}, \mathrm{Na}, \mathrm{P}, \mathrm{BD}$, MC, silt, and sand $(F=7.65, p=0.002$, Table 2$)$.

\section{Soil seed bank along with invasion rates}

The present study revealed the absence of seeds of woody species in the soil seed bank, and all seeds found were herbaceous. The invasion rate significantly affected soil seed bank abundance and the number of plant species. The highest soil seed bank density was recorded in the "medium" invasion area while the lowest was recorded in the "none" invasion area. The highest species richness was also recorded in the medium and high invasion areas followed by the low and none invasion areas (Table 3).

\section{AMF root colonization and spore abundance by invasion rate and site}

All sampled tree species were colonized by hyphal ( $\mathrm{HC})$, mycorrhizal (MHC), arbuscular (AC), and vesicle (VC) AMF structures in their roots. The percentage of root length colonization by different AMF structures (hyphal, arbuscule, and vesicle) was significantly $(p<0.05)$ different across invasion rates and sites (Table 4). The highest 
Table 2 The effect of $P$. juliflora species invasion rate on soil physical and chemical properties

\begin{tabular}{|c|c|c|c|c|c|}
\hline \multirow[t]{2}{*}{ Parameters } & \multirow[t]{2}{*}{ Site } & \multicolumn{4}{|l|}{ Invasion rate } \\
\hline & & High & Medium & Low & None \\
\hline \multirow[t]{3}{*}{ OC (\%) } & Amibara & $1.14 \pm 0.04$ & $1.14 \pm 0.13$ & $1.02 \pm 0.1$ & $1.89 \pm 0.25$ \\
\hline & Gewane & $1.64 \pm 0.09$ & $1.75 \pm 0.14$ & $0.52 \pm 0.07$ & $0.75 \pm 0.02$ \\
\hline & Mean & $1.39 \pm 0.12^{\mathrm{a}}$ & $1.37 \pm 0.27^{\mathrm{a}}$ & $0.77 \pm 0.06^{b}$ & $1.32 \pm 0.01^{a}$ \\
\hline \multirow[t]{3}{*}{ Ex. Na (cmol (+)/kg) } & Amibara & $1.02 \pm 0.44$ & $2.68 \pm 0.43$ & $2.96 \pm 0.29$ & $1.07 \pm 0.13$ \\
\hline & Gewane & $1.43 \pm 0.07$ & $3.21 \pm 0.61$ & $0.59 \pm 0.08$ & $0.81 \pm 0.26$ \\
\hline & Mean & $1.22 \pm 0.22^{b}$ & $2.94 \pm 0.35^{\mathrm{a}}$ & $1.77 \pm 0.54^{b}$ & $0.93 \pm 0.14^{b}$ \\
\hline \multirow[t]{3}{*}{ Ex. K $(\mathrm{cmol}(+) / \mathrm{kg})$} & Amibara & $0.89 \pm 0.05$ & $0.69 \pm 0.06$ & $0.87 \pm 0.27$ & $0.89 \pm 0.12$ \\
\hline & Gewane & $1.0 \pm 0.03$ & $1.01 \pm 0.04$ & $0.83 \pm 0.18$ & $0.99 \pm 0.18$ \\
\hline & Mean & $0.94 \pm 0.03^{\mathrm{a}}$ & $0.85 \pm 0.07^{\mathrm{a}}$ & $0.85 \pm 0.14^{\mathrm{a}}$ & $0.93 \pm 0.09^{a}$ \\
\hline \multirow[t]{3}{*}{ Ex. Ca $(\mathrm{cmol}(+) / \mathrm{kg})$} & Amibara & $11.73 \pm 0.72$ & $11.23 \pm 1.02$ & $8.23 \pm 0.77$ & $7.1 \pm 0.46$ \\
\hline & Gewane & $7.8 \pm 1.39$ & $9.83 \pm 0.54$ & $4.17 \pm 0.12$ & $5.73 \pm 0.12$ \\
\hline & Mean & $9.76 \pm 1.12^{\mathrm{a}}$ & $10.5 \pm 0.60^{\mathrm{a}}$ & $6.2 \pm 0.97^{b}$ & $6.41 \pm 0.37^{b}$ \\
\hline \multirow[t]{3}{*}{ Ex. Mg (cmol $(+) / \mathbf{k g})$} & Amibara & $2.4 \pm 0.5$ & $2.27 \pm 0.42$ & $2.77 \pm 0.43$ & $2.9 \pm 0.15$ \\
\hline & Gewane & $3.03 \pm 0.12$ & $2.8 \pm 0.25$ & $2.6 \pm 0.04$ & $2.87 \pm 0.24$ \\
\hline & Mean & $2.71 \pm 0.27^{\mathrm{a}}$ & $2.53 \pm 0.25^{\mathrm{a}}$ & $2.68 \pm 0.19^{a}$ & $2.88 \pm 0.12^{a}$ \\
\hline \multirow[t]{3}{*}{ Av. P (mg/kg) } & Amibara & $3.57 \pm 0.18$ & $2.56 \pm 0.59$ & $4.25 \pm 2.16$ & $4.19 \pm 0.38$ \\
\hline & Gewane & $24.04 \pm 1.34$ & $16.52 \pm 6.63$ & $2.31 \pm 0.75$ & $3.93 \pm 0.44$ \\
\hline & Mean & $13.8 \pm 4.61^{\mathrm{a}}$ & $9.53 \pm 4.31^{\mathrm{ab}}$ & $3.28 \pm 1.11^{b}$ & $1.32 \pm 0.26^{b}$ \\
\hline \multirow[t]{3}{*}{ TN (\%) } & Amibara & $0.11 \pm 0.01$ & $0.12 \pm 0.02$ & $0.08 \pm 0.01$ & $0.074 \pm 0.01$ \\
\hline & Gewane & $0.12 \pm 0.05$ & $0.14 \pm 0.01$ & $0.13 \pm 0.02$ & $0.11 \pm 0.01$ \\
\hline & Mean & $0.11 \pm 0.02^{\mathrm{a}}$ & $0.13 \pm 0.01^{a}$ & $0.10 \pm 0.01^{a}$ & $0.09 \pm 0.01^{a}$ \\
\hline \multirow[t]{3}{*}{ CEC (meq/100 g) } & Amibara & $42.3 \pm 0.86$ & $43.3 \pm 0.87$ & $46.3 \pm 0.37$ & $43.3 \pm 2.89$ \\
\hline & Gewane & $44.3 \pm 5.6$ & $49.6 \pm 3.49$ & $41.7 \pm 9.0$ & $44.1 \pm 7.21$ \\
\hline & Mean & $43.3 \pm 2.57^{\mathrm{a}}$ & $46.5 \pm 2.14^{\mathrm{a}}$ & $44.0 \pm 4.16^{a}$ & $43.8 \pm 3.47^{\mathrm{a}}$ \\
\hline \multirow[t]{3}{*}{$\mathrm{BD}\left(\mathrm{g} / \mathrm{cm}^{3}\right)$} & Amibara & $1.12 \pm 0.04$ & $1.23 \pm 0.03$ & $1.28 \pm 0.05$ & $1.21 \pm 0.19$ \\
\hline & Gewane & $0.96 \pm 0.03$ & $1.12 \pm 0.01$ & $1.38 \pm 0.01$ & $1.39 \pm 0.02$ \\
\hline & Mean & $1.07 \pm 0.05^{b}$ & $1.17 \pm 0.02^{\mathrm{ab}}$ & $1.32 \pm 0.03^{a}$ & $1.30 \pm 0.09^{a}$ \\
\hline \multirow[t]{3}{*}{ MC (\%) } & Amibara & $13.22 \pm 0.66$ & $8.94 \pm 0.33$ & $8.19 \pm 0.47$ & $5.47 \pm 0.74$ \\
\hline & Gewane & $15.45 \pm 1.62$ & $10.46 \pm 0.38$ & $6.04 \pm 0.26$ & $4.41 \pm 0.24$ \\
\hline & Mean & $14.33 \pm 0.92^{\mathrm{a}}$ & $9.69 \pm 0.40^{b}$ & $7.11 \pm 0.53^{c}$ & $4.94 \pm 0.42^{d}$ \\
\hline \multirow[t]{3}{*}{ Clay (\%) } & Amibara & $41.7 \pm 2.9$ & $33.7 \pm 10.7$ & $45.1 \pm 1.3$ & $27.1 \pm 2.7$ \\
\hline & Gewane & $42.4 \pm 9.2$ & $46.4 \pm 4.2$ & $35.1 \pm 1.8$ & $22.4 \pm 1.2$ \\
\hline & Mean & $42.0 \pm 4.3^{a}$ & $40.0 \pm 5.8^{\mathrm{ab}}$ & $40.0 \pm 2.4^{\mathrm{ab}}$ & $24.7 \pm 1.6^{\mathrm{b}}$ \\
\hline \multirow[t]{3}{*}{ Silt (\%) } & Amibara & $43.3 \pm 2.4$ & $40.7 \pm 5.2$ & $30.0 \pm 2.3$ & $39.3 \pm 1.3$ \\
\hline & Gewane & $49.3 \pm 7.1$ & $39.3 \pm 7.4$ & $7.3 \pm 1.8$ & $39.3 \pm 3.3$ \\
\hline & Mean & $46.3 \pm 3.59^{a}$ & $40.0 \pm 4.06^{\mathrm{a}}$ & $18.66 \pm 5.23^{b}$ & $39.3 \pm 1.60^{a}$ \\
\hline \multirow[t]{3}{*}{ Sand (\%) } & Amibara & $14.9 \pm 0.7$ & $25.6 \pm 6.4$ & $24.9 \pm 1.3$ & $33.6 \pm 2.3$ \\
\hline & Gewane & $8.3 \pm 2.4$ & $14.3 \pm 4.1$ & $57.6 \pm 1.2$ & $38.3 \pm 2.4$ \\
\hline & Mean & $11.6 \pm 1.8^{b}$ & $19.9 \pm 4.24^{b}$ & $41.26 \pm 7.34^{a}$ & $35.9 \pm 1.8^{\mathrm{a}}$ \\
\hline
\end{tabular}

Different superscript letters indicate significant differences $(p<0.05)$ among invasion rates according to Tukey's HSD test

("none"; P. juliflora cover $\leq 3 \%$ ), low cover ("low"; P. juliflora cover 3-40\%), intermediate cover ("med"; P. juliflora cover 40-60\%), and high cover ("high"; P. juliflora cover $>60 \%)$

Values are mean \pm SEM (standard errors of the mean)

OC organic carbon, Ex. Na exchangeable sodium, Ex. K exchangeable potassium, Ex. Ca exchangeable calcium, Ex. Mg exchangeable magnesium, Av. $P$ available phosphorus, $T N$ total nitrogen, $C E C$ cation exchange capacity, $B D$ bulk density, $M C$ moisture content 
Table 3 Number and abundance of species in soil seed bank by invasion rate

\begin{tabular}{|c|c|c|c|c|c|}
\hline \multirow[t]{2}{*}{ Parameters } & \multirow[t]{2}{*}{ Site } & \multicolumn{4}{|l|}{ Invasion rate } \\
\hline & & High & Medium & Low & None \\
\hline \multirow[t]{3}{*}{ Density } & Amibara & $65.2 \pm 1.2$ & $45.0 \pm 0.89$ & $25.0 \pm 0.54$ & $15.0 \pm 0.78$ \\
\hline & Gewane & $56.0 \pm 1.56$ & $86.0 \pm 1.78$ & $8.0 \pm 1.08$ & $17.0 \pm 1.42$ \\
\hline & Mean & $60.5 \pm 0.76^{b}$ & $65.5 \pm 3.46^{\mathrm{a}}$ & $16.5 \pm 1.43^{c}$ & $16.0 \pm 0.16^{d}$ \\
\hline \multirow[t]{3}{*}{ Species richness } & Amibara & $13.0 \pm 0.52$ & $12.6 \pm 0.72$ & $8.4 \pm 0.25$ & $6.5 \pm 0.34$ \\
\hline & Gewane & $15.0 \pm 0.45$ & $16.2 \pm 0.56$ & $9.4 \pm 0.24$ & $8.0 \pm 0.21$ \\
\hline & Mean & $14.0 \pm 0.43^{a}$ & $14.4 \pm 0.63^{a}$ & $8.9 \pm 0.23^{b}$ & $7.3 \pm 0.27^{c}$ \\
\hline
\end{tabular}

("none"; P. juliflora cover $\leq 3 \%$ ), low cover ("low"; P. juliflora cover 3-40\%), intermediate cover ("med"; P. juliflora cover 40-60\%), and high cover ("high"; P. juliflora cover $>60 \%)$. Different superscript letters indicate significant differences $(p<0.05)$ among invasion rates according to Tukey's HSD test

AMF colonization percentage of $\mathrm{HC}$ and $\mathrm{MHC}$ was observed at high invasion levels, followed by medium and low invasion rates across both sites (Table 4). The AC and VC structures did not show any consistency in their trend with increasing invasion rate. The percentage of root length colonization by spore abundance (number of spores per $25 \mathrm{~g}$ of dry soil) was significantly $(F=139.14, p$ $<0.05$ ) different across invasion rates of $P$. juliflora (Table
4). The highest spore abundance was observed at high invasion rates, followed by medium and low invasion rates in both sites (Table 4).

\section{Correlation between soil properties, AMF associations, and invasion rate}

AMF spore abundance as well as $\mathrm{HC}$ was highly negatively correlated with increasing invasion rate $(r=-$

Table 4 The effect of $P$. juliflora invasion rates and site on AMF root colonization community structures

\begin{tabular}{|c|c|c|c|c|}
\hline \multirow[t]{2}{*}{ Parameters } & \multirow{2}{*}{$\begin{array}{l}\text { Invasion } \\
\text { rate }\end{array}$} & \multicolumn{3}{|l|}{ Sites } \\
\hline & & Amibara & Gewane & Mean \\
\hline \multirow[t]{4}{*}{ HC (\%) } & High & $81.4 \pm 1.3$ & $74.9 \pm 1.3$ & $78.2 \pm 1.1^{a}$ \\
\hline & Medium & $72.7 \pm 1.3$ & $70.3 \pm 1.0$ & $71.6 \pm 0.9^{b}$ \\
\hline & Low & $69.3 \pm 1.3$ & $67.7 \pm 1.1$ & $68.5 \pm 0.8^{b}$ \\
\hline & None & $70.8 \pm 1.0$ & $72.5 \pm 1.2$ & $71.7 \pm 0.8^{b}$ \\
\hline \multirow[t]{4}{*}{ MHC (\%) } & High & $70.6 \pm 1.5$ & $66.1 \pm 1.4$ & $68.4 \pm 1.1^{\mathrm{a}}$ \\
\hline & Medium & $66.9 \pm 1.5$ & $64.1 \pm 1.5$ & $65.5 \pm 0.8^{\mathrm{ab}}$ \\
\hline & Low & $63.8 \pm 1.5$ & $61.3 \pm 1.5$ & $62.6 \pm 1.1^{b}$ \\
\hline & None & $63.5 \pm 1.5$ & $63.2 \pm 1.7$ & $63.4 \pm 1.1^{b}$ \\
\hline \multirow[t]{4}{*}{ AC (\%) } & High & $22.3 \pm 1.0$ & $19.1 \pm 0.8$ & $20.7 \pm 0.7^{\mathrm{a}}$ \\
\hline & Medium & $19.0 \pm 0.9$ & $14.3 \pm 1.0$ & $16.6 \pm 0.8^{b}$ \\
\hline & Low & $15.9 \pm 1.0$ & $18.2 \pm 0.7$ & $17.1 \pm 0.6^{b}$ \\
\hline & None & $15.8 \pm 1.0$ & $16.5 \pm 1.1$ & $16.2 \pm 0.7^{b}$ \\
\hline \multirow[t]{4}{*}{ VC (\%) } & High & $26.6 \pm 0.8$ & $26.7 \pm 0.7$ & $26.7 \pm 0.5^{\mathrm{a}}$ \\
\hline & Medium & $28.7 \pm 0.8$ & $26.7 \pm 0.7$ & $27.7 \pm 0.6^{a}$ \\
\hline & Low & $20.7 \pm 1.0$ & $21.3 \pm 0.8$ & $21.1 \pm 0.6^{c}$ \\
\hline & None & $23.5 \pm 1.0$ & $23.6 \pm 0.8$ & $23.6 \pm 0.6^{b}$ \\
\hline \multirow[t]{4}{*}{ Number of spores } & High & $497 \pm 14.7$ & $459.2 \pm 7.6$ & $478 \pm 8.8^{b}$ \\
\hline & Medium & $382.4 \pm 10.3$ & $337.5 \pm 19.3$ & $359.9 \pm 11.4^{c}$ \\
\hline & Low & $271.5 \pm 8.2$ & $236.2 \pm 9.6$ & $253.8 \pm 6.9^{d}$ \\
\hline & None & $517.4 \pm 24.1$ & $544.4 \pm 16.5$ & $530.9 \pm 14.6^{a}$ \\
\hline
\end{tabular}

("none"; P. juliflora cover $\leq 3 \%$ ), low cover ("low"; P. juliflora cover 3-40\%), intermediate cover ("med"; P. juliflora cover 40-60\%), and high cover ("high"; P. juliflora cover $>60 \%$ )

Different superscript letters indicate significant differences $(p<0.05)$ among invasion rates according to Tukey's HSD test $H C$ hyphal colonization, $M H C$ mycorrhizal colonization, $A C$ arbuscular colonization, $V C$ vesicular colonization 
$0.86, p<0.001 ; r=-0.57, p<0.01$, respectively; Additional file 1). Soil properties such as soil OC, Ca, P, $\mathrm{BD}, \mathrm{MC}$, and the proportion of silt were significantly negatively correlated with increasing invasion rate (Additional file 1). Spore abundance was significantly and positively correlated with $\mathrm{HC}, \mathrm{OC}, \mathrm{P}, \mathrm{MC}$, and the proportion of silt. $\mathrm{HC}$ was significantly and positively correlated with $\mathrm{TN}, \mathrm{MC}$, and silt but significantly and negatively correlated with $\mathrm{BD}$ and clay (Additional file 1).

\section{Discussion}

\section{Plant species composition and stand structure}

Our findings indicated that $P$. juliflora invasion strongly suppressed native plant species in the study area. Most woody species individuals had a stem diameter of less than $5 \mathrm{~cm}$ across most invasion rates, indicating a high natural recruitment, predominately by $P$. juliflora. This trend is likely related to $P$. juliflora's inherent characteristics to outcompete the native flora for scarce natural resources like water, space, soil nutrient, and light (Shiferaw et al. 2004). Our results agree with Getachew et al. (2012) and Nascimento et al. (2014), who reported that leaf, bark, and root aqueous extract of $P$. juliflora at higher concentrations can inhibit the seed germination and seedling growth of native woody and herbaceous plants, likely due to its allelopathic character, which resulted in lower native plant diversity. Invasive species also provide a shady condition in the systems that keep native forage species from getting quality light, essential resources for germination, survival, and growth (Vetaas 1992; Pons 2000). The shady condition in combination with other plant stresses (competition for water and soil nutrients) contributes to the difficulty of growing native forage species under dense thickets of invasive species (Flores and Jurado 2003). In contrast, a positive impact of $P$. juliflora on plant density and diversity was actually reported from Australia (Van Klinken et al. 2006) and India (Kumar and Mathur 2014). The future species composition of the plant community under invasion is dependent on whether the sites provide sufficient resources (Kimmins 1997).

Given the long time since its invasion in the Afar Region in the 1970s, and given this species' fast growth, we expected large-sized trees to dominate $P$. juliflora populations. The higher number of small-sized trees, however, is probably due to continuous commercial and non-commercial harvest of large-sized trees for fuelwood and charcoal production (Ilukor et al. 2016). The Regional Government had enacted a regional proclamation that aimed at controlling $P$. juliflora through utilization and allowed locally established cooperatives to harvest the species for commercial purposes (Gebru 2008). Cooperatives have been selectively harvesting the larger trees since then, which yielded small-sized sprouts from the cut stump (Gebru 2008). Our findings are similar with those observed in South Africa and Kenya, where $P$. juliflora was composed of a young population and sustained recruitment, even in the absence of anthropogenic effects (Muturi et al. 2013; Shackleton et al. 2015).

\section{Soil seed bank affected by $P$. juliflora invasion}

In our study, we did not find any woody species seeds in the soil seed bank and all seeds found were herbaceous. This lack of woody vegetation seeds might be related to the absence of seed production as the system is dominated by one species (Tybirk et al. 1992), or seed predation and mortality due to aging and loss of viability or pathogens (Harper 1977; Thompson 1987). There might also be an induced different dormancy period to stabilize population dynamics against local extinction of the population under unpredictable environmental conditions (Thompson 1987). Woody plants generally have low seed numbers (Teketay and Granström 1995) and are short-lived in the soil (Teketay 1997). The reason why no $P$. juliflora seeds was found in the soil seed bank across the different invasion rates could be that the soil seed bank was collected at the end of the dry season, when all seeds had germinated. Generally, we found only few woody species growing in the study area, similar to other studies in northern Ethiopia (Tekle and Bekele 2000; Mengistu 2001), but in contrast to the Afromontane and rift valley areas (Senbeta 1998; Argaw et al. 1999).

The high seed number of herbaceous and grass seeds we found both in the high invasion rate and the open ("none") may be linked to a prolonged dry season, which helps with the accumulation of dormant seeds where no $P$. juliflora grew. In contrast, the high seed numbers under high encroachment might show that $P$. juliflora stands can protect seeds from being washed or blown away by water and wind erosion as other woody species do. The seed densities found in this study are comparable with investigations in other dry tropical ecosystems that have revealed $48-1890$ seeds $/ \mathrm{m}^{2}$ (Garwood 1989) and 8-67 species. In our study, the soil seed bank types in the different invasion rates were similar while the ground cover of standing herbs differed substantially. The high levels of similarity in the soil seed bank indicate that the invaded area, if cleared, can regrow nearnatural vegetation. The high number of herbaceous and grass species in invaded sites shows the role of $P$. juliflora in providing vegetative protection cover that could help in reducing degradation through erosion. For successful woody vegetation reestablishment, however, the seed banks may require supplementary planting of seedlings (Tekle and Bekele 2000). 
Soil properties along with invasion rates and sites Our results showed that $P$. juliflora invasion harbored increased soil nutrients, which was also found for P. juliflora by other studies (Tiedemann and Klemmedson 1977; Aggarwal 1980) and for other tree and shrub species at high density in dryland environments (Mazzarino et al. 1991; Rostagno et al. 1991). The enrichment of edaphic variables under the higher canopy can be explained by the redistribution of nutrients absorbed by the root system to the area (Treydte et al. 2007), the biological fixation of nitrogen by symbiotic rhizobium (Geesing et al. 2000), and through a higher organic matter input into the soil (Ilukor et al. 2016). Recently, some pastoralists have altered their way of life from livestock production to crop production in response to bush encroachment in rangelands (Mehari 2015; Ilukor et al. 2016). Therefore, the improvements of soil properties due to the invasion of $P$. juliflora are an important aspect for potential crop production, or reseeding of rangelands, particularly in the otherwise arid and nutrientpoor rangelands of Afar.

\section{AMF root colonization and spore abundance}

Our result showed the highest AMF colonization percentage of $\mathrm{HC}$ and $\mathrm{MHC}$ at high invasion categories. AMF structures (hyphal, arbuscule, and vesicle) were found in all sampled trees, indicating that dryland plant species with poorly developed roots commonly require mycorrhiza for their growth, reproduction, and survival in a stressful environment (Hailemariam et al. 2018). Tropical dryland species positively respond to inoculation with different AM fungal species by increased biomass, plant height, stem girth, number of leaves, and root length (Reena and Bayagaraj 1990; Caravaca et al. 2003). The outgrowth of mycorrhizal hyphae into the soil far beyond the root or root hair zone considerably increases the efficiency in attracting poorly mobile nutrients and translocating them to the root (Haselwandter and Bowen 1996; Joner et al. 2000). The larger soil volume explored and exploited increases the nutrient uptake by shortening the distance that nutrients have to diffuse from the soil to the roots (Kungu 2006), thereby increasing plant tissue $\mathrm{P}, \mathrm{K}, \mathrm{N}, \mathrm{Zn}, \mathrm{Mg}, \mathrm{Cu}$, and $\mathrm{Ca}$ mass fractions under drought conditions (Reena and Bayagaraj 1990; Huat et al. 2002).

In addition, mycorrhizal hyphae can penetrate soil pores that otherwise would be inaccessible to roots and may compete more effectively with saprotrophic microorganisms for recently mineralized nutrients than the plants themselves (Smith and Read 2008). AMF spore abundance can be promoted by appropriate management (Silva et al. 2005), e.g., by exclosures that increase herbaceous cover and decrease surface erosion. Therefore, the invaded $P$. juliflora sites confirm that this vegetation stand, particularly at high density, can show higher propagule densities than degraded bushland and cultivated areas (Michelsen and Rosendahl 1989; Carpenter et al. 2001). Hence, after managing and harvesting $P$. juliflora stands, immediate seeding and/or supporting of native vegetation will foster a healthy rangeland restoration in the long run.

\section{Conclusions}

Our study suggests that Prosopis juliflora might have a positive effect on improving the soil properties and mycorrhizal activities. In addition, $P$. juliflora might not have such a negative effect on soil seed bank abundance and number of species as we had expected. Hence, although $P$. juliflora is considered as ecological challenge, this study highlights the potential benefits of $P$. juliflora in improving some ecological indicators. The positive effect of $P$. juliflora invasion on most soil physical and chemical properties calls out for sustainable management practices. Further research on the sustainable way of management of $P$. juliflora should be conducted to balance the negative and positive effects of $P$. juliflora on economic, social, and environmental aspects of the study area.

\section{Supplementary information}

Supplementary information accompanies this paper at https://doi.org/10. 1186/s13717-020-00240-x.

Additional file 1. Pearson correlation coefficient of AMF associations with soil properties along invasion rate.

\section{Abbreviations}

AC: Arbuscular colonization; AM: Arbuscular mycorrhiza; AMF: Arbuscular mycorrhiza fungi; BD: Bulk density; CEC: Cation exchange capacity; EARO: Ethiopian Agricultural Research Organization; HADRA: Henry Doubleday Research Association; HC: Hyphal colonization;

INVAM: International Culture Collection of (Vesicular) Arbuscular Mycorrhizal Fungi; MAE: Millennium Ecosystem Assessment; MC: Moisture content; MHC: Mycorrhizal hyphal colonization; OC: Organic carbon; PVLG: Polyvinyl alcohol-lactoglycerol; RCD: Root collar diameter; SEM: Standard errors of the mean; UNCCD: United Nations Convention to Combat Desertification; VC: Vesicular colonization

\section{Acknowledgements}

This study was financed by the Deutsche Gesellschaft fuer Internationale Zusammenarbeit (GIZ) and the German Federal Ministry for Economic Cooperation and Development. We thank the field assistants for their administrative support and activities in the field. The two anonymous reviewers are duly acknowledged for the critical comments and improvements on the earlier version of this manuscript.

\section{Authors' contributions}

$\mathrm{AE}$ analyzed and interpreted the inventory data regarding the species composition and prepared the first draft manuscript. EB analyzed and interpreted the soil seed bank, soil nutrient, and mycorrhizal-related data. AT has generally guided the manuscript. All authors read and approved the final manuscript.

\section{Availability of data and materials}

The datasets used and/or analyzed during the current study are available from the corresponding author on reasonable request. 


\section{Ethics approval and consent to participate}

Not applicable

\section{Consent for publication}

Not applicable

\section{Competing interests}

The authors declare that they have no competing interests.

\section{Author details}

${ }^{1}$ Central Ethiopia Environment and forestry Research Center (CEEFRC), Ethiopian Environment and Forestry Research Institute (EEFRI), P.O. Box 30708, Addis Ababa, Ethiopia. ${ }^{2}$ Agroecology in the Tropics and Subtropics, University of Hohenheim, Stuttgart, Germany. ${ }^{3}$ Biodiversity Conservation and Ecosystem Management, Nelson Mandela African Institution of Science and Technology, Arusha, Tanzania. ${ }^{4}$ School of Life Sciences and Bioengineering, Nelson Mandela African Institution of Science and Technology, Arusha, Tanzania. ${ }^{5}$ Department of Land Resources Management and Environmental Protection, Mekelle University, P.O. Box 231, Mekelle, Ethiopia.

Received: 3 March 2020 Accepted: 10 June 2020

Published online: 30 June 2020

\section{References}

Aggarwal RK (1980) Physico-chemical status of soil under Khejri (Prosopis cineraria Linn). In: Mann HS, Saxena SK (eds) Khejri (Prosopis cineraria Linn) in the Indian Desert. Central Arid Zone Research Institute, Jodhpur

Archer S, Boutton T, Hibbard K (2001) Trees in grasslands: Biogeochemical Consequences of woody plant expansion. In: Schulze E, Harrison S, Heimann M, Holland E, Lloyd J, Prentice, I Schimel D (eds) Global Biogeochemical Cycles in the Climate System. Academic Press, San Diego

Archer S (2008) Proliferation of woody plants in grasslands and savannas: a bibliography. University of Arizona. http://ag.arizona.edu/research/archer/

Argaw M, Teketay D, Osslon M (1999) Soil seed flora, germination and regeneration pattern of woody species in acacia woodland of the rift valley in Ethiopia. J Arid Environ 43:411-435

Barbosa da Silva FH, Arieira J, Parolin P, Nunes da Cunha C, Junk WJ (2016) Shrub encroachment influences herbaceous communities in flooded grasslands of a neotropical savanna wetland. Appl Veg Sci 19:391-400

Barea JM, Palenzuela J, Cornejo P, Sánchez-Castro I, Navarro-Fernández C, LopézGarcía A, Estrada B, Azcón R, Ferrol N, Azcón-Aguilar C (2011) Ecological and functional roles of mycorrhizas in semi-arid ecosystems of Southeast Spain. J Arid Environ 75:1292-1301

Birhane E, Treydte AC, Eshete A, Solomon N, Hailemariam M (2017) Can rangelands gain from bush encroachment? Carbon stocks of communal grazing lands invaded by Prosopis juliflora. J Arid Environ 141:60-67

Blake GR, Hartge KH (1986) Bulk density. In: Klute A (ed) Methods of soil analysis. Part 1 - physical and mineralogical methods, 2nd edn, Madison

Blench R (2001) 'You can't go home again': pastoralism in the new millennium. http://www.odi.org.uk/work/projects/pdn/eps.pdf. Accessed 15 Jan 2020

Bremner JM, Mulvaney CS (1982) Total nitrogen. In: Page AL, Miller RH, Keeny DR (eds) Methods of soil analysis. American Society of Agronomy and Soil Science Society of America, Madison

Brundrett M, Melville L, Peterson L (1994) Practical methods in mycorrhizal research. Mycologue, Ontario

Caravaca F, Barea JM, Palenzuela J, Fiqueroa D, Alquacil MM, Roldan A (2003) Establishment of shrub species in a degraded semi-arid site after inoculation with native or allochthonous arbuscular mycorrhizal fungi. Appl Soil Ecol 22: 103-111

Carpenter FL, Mayorga SP, Quintero EG, Schroeder M (2001) Land-use and erosion of a Costa Rican Ultisol affect soil chemistry, mycorrhizal fungi and early regeneration. For Ecol Manag 144:1-17

Dalle G, Brigittie M, Johannes I (2005) Plant biodiversity and ethnobotany of Borana pastoralists in southern Oromia, Ethiopia. Econ Bot 59:43-65

Davies J, Poulsen L, Schulte-Herbrüggen B, Mackinnon K, Crawhall N, Henwood WD, Dudley N, Smith J, Gudka M (2012) Conserving dryland biodiversity. International Union for Conservation of Nature, Nairobi

EARO (Ethiopian Agricultural Research Organization) and HADRA (Henry Doubleday Research Association) (2005) Controlling the spread of Prosopis in Ethiopia by its utilization. EARO and HADRA, Addis Ababa
Eldridge DJ, Bowker MA, Maestre FT, Roger E, Reynolds JF, Whitford WG (2011) Impacts of shrub encroachment on ecosystem structure and functioning: towards a global synthesis. Ecol Lett 14:709-722

Eldridge DJ, Soliveres S (2015) Are shrubs really a sign of declining ecosystem function? Disentangling the myths and truths of woody encroachment in Australia. Australian J Bot 62:594-608

Eshete A, Teketay D, Hulten H (2005) The socio-economics importance and status of population of Boswellia papyrifera (Del.) Hochst in northern Ethiopia: the case of North Gondar zone. Forests Trees Liveli 5:55-74

Ffolliott P, Dawson JO, Fisher JT, Moshe I, Fulbright TE, Al Musa A, Johnson C, Verburg P (2002) Dry land environments. Arid Lands Newsl 52:1-14

Flores J, Jurado E (2003) Are nurse-protégé interactions more common among plants from arid environments? J Veg Sci 14:911-916

Garwood NC (1989) Tropical soil seed banks: a review. In: Leck MA, Parker VT, Simpson RL (eds) Ecology of soil seed banks. Academic Press, San Diego

Gebru G (2008) Experiences on Prosopis management - case of Afar region. FARM-Africa, Addis Ababa

Gee GW, Bauder JW (1982) Particle size analysis in methods of soil analysis. Chemical and microbiological properties. Agronomy no. 9, 2nd edn. Soil Science Society of America, Medison

Geesing D, Felker P, Bingham RL (2000) Influence of mesquite (Prosopis glandulosa) on soil nitrogen and carbon development: implications for global carbon sequestration. J Arid Environ 46:157-180

Georgis K (2005) The role and contribution of dryland biodiversity in Ethiopia. Paper presented at the regional workshop of biodiversity. Dar Es Salaam University, Dar Es Salaam

Getachew S, Demissew S, Woldemariam T (2012) Allelopathic effects of the invasive Prosopis juliflora (Sw.) DC. on selected native plant species in middle awash, southern Afar rift of Ethiopia. Manage Biol Invasions 3(2):105-114

Hailemariam M, Birhane E, Gebresamuel G, Gebrekiros A, Desta Y, Alemayehu A Muruts H, Araya T, Norgrove L (2018) Arbuscular mycorrhiza effects on Faidherbia albida (Del.) A. Chev. growth under varying soil water and phosphorus levels in northern Ethiopia. Agrofor Syst 92:485-498

Harper JL (1977) Population biology of plants. Academic Press, New York

Haselwandter K, Bowen GD (1996) Mycorrhizal relations in trees for agroforestry and land rehabilitation. For Ecol Manag 81:1-17

Havstad KM, Huenneke LF, Schlesinger WH (eds) (2006) Structure and function of a Chihuahuan Desert ecosystem: the Jornada Basin long-term ecological research site. Oxford University Press, New York

Hawando T (1997) Desertification in Ethiopian highlands (Rala report no. 200). Norwegian Church AID, Addis Ababa

Hedberg I (1996) Flora of Ethiopia and Eritrea. In: van der Maesen LJG, van der Burgt XM, van Medenbach de Rooy JM (eds) The biodiversity of African plants: proceedings XIVth AETFAT, Wageningen, 1994. Springer, Dordrecht

Huat OK, Awang K, Hashim A, Majid N (2002) Effects of fertilizer and vesicular arbuscular mycorrhizas on the growth and photosynthesis of Azadirachto excelsa (Jack.) Jacobs seedlings. For Ecol Manag 158:51-58

Ilukor J, Rettberg S, Treydte AC, Birner R (2016) To eradicate or not to eradicate? Recommendations on Prosopis juliflora management in Afar, Ethiopia, from an interdisciplinary perspective. Pastor Res Policy Pract 6:14

Joner EJ, Arale IM, Vosatka M (2000) Phosphatase activity of extra-radical arbuscular mycorrhizal fungi: a review. Plant Soil 226:199-210

Kimmins JP (1997) Forest ecology: a foundation for sustainable management, 2nd edn. Prentice-Hall, Inc., New Jersey

Knapp AK, Briggs JM, Collins SL, Archer SR, Bret-Harte MS, Ewers BE, Peters DP, Young DR, Shaver GR, Pendall E, Cleary MB (2008) Shrub encroachment in north American grasslands: shifts in growth form dominance rapidly alters control of ecosystem carbon inputs. Glob Chang Biol 14:615-623

Kotu BH (2009) From pasture land to farm plots, triggers and motivations for land use changes in Afar, Ethiopia. Paper presented at the 2009 Conference, Beijing, 16-22 August 2009

Kumar S, Mathur M (2014) Impact of invasion by Prosopis juliflora on plant communities in arid grazing lands. Trop Ecol 55:233-246

Kungu JB (2006) Effect of vesicular-arbuscular mycorrhiza (VAM) inoculation on growth performance of Senna spectabilis. School of Pure and Applied Sciences, Kenyatta University, Nairobi, pp 433-446

Maestre FT, Eldridge DJ, Soliveres S (2016) A multifaceted view on the impacts of shrub encroachment. Appl Veg Sci 19:369-370

Manchester SJ, Bullock JM (2000) The impact of non-native species on UK biodiversity and the effectiveness of control. J Appl Ecol 37:845-864 
Mazzarino MJ, Oliva L, Nunez A, Nunez G, Buffa E (1991) Nitrogen mineralization and soil fertility in the dry Chaco ecosystem (Argentina). Soil Sci Soc Am J 55:515-522

MEA (Millennium Ecosystem Assessment) (2005) Ecosystems and human wellbeing: Our human planet: summary for decision-makers. Island Press, Washington, DC, p 109

Mehari ZH (2015) The invasion of Prosopis juliflora and Afar pastoral livelihoods in the middle awash area of Ethiopia. Ecol Process 4:13

Mengistu T (2001) The role of area closures in the recovery of woody vegetation in degraded hillsides of Biyo and Tiya, central and northern Ethiopia. M.Sc. Thesis. Swedish University of Agricultural Sciences

Michelsen A, Rosendahl S (1989) Propagule density of VA-mycorrhizal fungi in semi-arid bushland in Somalia. Agric Ecosyst Environ 29:295-301

Muturi GM, Poorter L, Mohren GMJ, Kigomo BN (2013) Ecological impacts of Prosopis species invasion in Turkwel riverine forest, Kenya. J Arid Environ 92: 89-97

Nascimento CE, Tabarelli M, CAD S, da Leal IR, Souza Tavares W, Serrão JE, Zanuncio JC (2014) The introduced tree Prosopis juliflora is a serious threat to native species of the Brazilian Caatinga vegetation. Sci Total Environ 481: 108-113

Oba G, Post E, Syvertsen PO, Stenseth NC (2000) Bush cover and range condition assessments in relation to landscape and grazing in southern Ethiopia. Landsc Ecol 15:535-546

Olsen SR, Sommers LE (1982) Phosphorus. In: Page AL (ed) Methods of soil analysis, part 2 chemical and microbiological properties, 2nd edn. American Society of Agronomy, Soil Science Society of America, Madison

Pasiecznic NM, Harris PJC, Smith S (2004) Identifying tropical Prosopis species: a field guide. HADRA, Coventry

Pasiecznik NM, Felker P, Harris PJC, Harsh LN, Cruz G, Tewari JC, Cadorer K, Maldonado LJ (2001) The Prosopis juliflora-Prosopis pallida complex. HADRA Coventry

Pittarello M, Probo M, Lonati M, Lombardi G (2016) Restoration of sub-alpine shrub-encroached grasslands through pastoral practices: effects on vegetation structure and botanical composition. Appl Veg Sci 19:381-390

Pons TL (2000) Seed responses to light. In: Fenner M (ed) Seeds: The ecology of regeneration in plant communities, 2nd edn, CABI Publishing, Wallingford

Redford HK, Taber A, Simonetti JA (1990) There is more to biodiversity than the tropical rainforest. Conserv Biol 4(3):328-330

Reena J, Bayagaraj DJ (1990) Growth stimulation of Tamarindus indica by selected VA mycorrhizal fungi. World J Microbiol Biotechnol 6:59-63

Rogers P, Nunan F, Fentie A (2017) Reimagining invasions: the social and cultural impacts of Prosopis on pastoralists in southern Afar, Ethiopia. Pastor Res Policy Pract 7:22

Rostagno CM, Del Valle HF, Videla L (1991) The influence of shrubs on some chemical and physical properties of an aridic soil in North-Eastern Patagonia, Argentina. J Arid Environ 20:179-188

Saco P, Willgoose G, Hancock G (2007) Eco-geomorphology of banded vegetation patterns in arid and semi-arid regions. Hydrol Earth Syst Sci Discuss 11:1717-1730

Senbeta F (1998) Native woody species regeneration under the canopies of tree plantation at Munessa-Shashemene Forest project area, southern Oromia, Ethiopia. M.Sc. Thesis. Swedish University of Agricultural Sciences

Shackleton RT, Le Maitre DC, Richardson DM (2015) Prosopis invasions in South Africa: population structures and impacts on native tree population stability. J Arid Environ 114:70-78

Shiferaw H, Teketay D, Nemomissa S, Assefa F (2004) Some biological characteristics that foster the invasion of Prosopis juliflora (Sw.) DC. at middle awash rift valley area, North-Eastern Ethiopia. J Arid Environ 58:135-154

Silva GA, Trufem SFB, Saggin-Júnior OJ, Maia LC (2005) Arbuscular mycorrhiza fungi in a semiarid copper mining area in Brazil. Mycorrhiza 15:47-53

Smith HG, Öckinger E, Rundlöf M (2010) Biodiversity and the landscape ecology of agri-environment schemes. Asp Appl Biol 100:225-232

Smith SE, Read DJ (2008) Mycorrhizal symbiosis, 3rd edn. Academic Press, London

Soliveres S, Maestre FT, Eldridge D, Delgado-Baquerizol M, Quero JL, Bowker MA, Gallardo A (2014) Plant diversity and ecosystem multifunctionality peak at intermediate levels of woody cover in global drylands. Glob Ecol Biogeogr 23:1408-1416

Tamire H (1997) Desertification in Ethiopian highlands. RALA report no. 200. Norwegian Church AID, Addis Ababa
Teketay D (1997) The impact of clearing and converting dry Afromontane forests into permanent arable land on the composition and density of soil seed banks. Acta Oecol 18:557-573

Teketay D, Granström A (1995) Soil seed banks in dry Afromontane forests of Ethiopia. J Veg Sci 6:777-786

Tekle K, Bekele T (2000) The role of soil seed banks in the rehabilitation of degraded hillslopes in southern Wello, Ethiopia. Biotropica 32:23-32

Thompson K (1987) Seed and seed banks. New Phytol 106:23-24

Tiedemann AR, Klemmedson JO (1977) Effect of mesquite trees on vegetation and soils in the desert grassland. J Range Manag 30:361-367

Treydte AC, Heitkönig IM, Prins HH, Ludwig F (2007) Trees enhance grass quality for herbivores in African savannas perspect. Plant Ecol Evol Syst 8:197-205

Tybirk K, Schmidt LH, Hauser T (1992) Notes on soil seed banks of African acacias. Afr J Ecol 32:327-330

UNCCD (2000) An introduction to the United Nations convention to combat desertification. http://www.unccd.int. Accessed 18 Dec 2019

van der Heijden MGA, Sanders IR (2002) Arbuscular mycorrhizal fungi as a determinant of plant diversity: in search for underlying mechanisms and general principles. In: van der Heijden MGA, Sanders IR (eds) Mycorrhizal ecology. Springer, Berlin

van Klinken RD, Graham J, Flack LK (2006) Population ecology of hybrid mesquite (Prosopis species) in Western Australia: how does it differ from native range invasions and what are the implications for impacts and management? Biological Invasions 8:727-41

Van Ranst E, Verloo M, Demeyer A, Pauwels JM (1999) Manual for the soil chemistry and fertility laboratory: analytical methods for soils and plants: equipment, and management of consumables. University of Ghent, Belgium, pp 96-105

Van Reeuwijk P (1993) Procedures for soil analysis, 4th edn. International Soil Reference and Information Center, the Netherlands

Vetaas OR (1992) Micro-site effects of trees and shrubs in dry savanna. J Veg Sc 3:337-344

Walker BH, Noy-Meir I (1992) Aspects of the stability and resilience of savanna ecosystems. In: Huntley BJ, Walker BH (eds) Ecology of tropical savannas. Springer-Verlag, New York

Wang B, Qui YL (2006) Phylogenetic distribution and evolution of mycorrhizas in land plants. Mycorrhiza 16:299-363

Ward D (2005) Do we understand the causes of bush encroachment in Africa savannas? Africa J Range Forage Sci 22:101-105

White RP, Nackoney J (2003) Drylands, people, and ecosystem goods and services: a web-based geospatial analysis. http://forests.wri.org. Accessed 8 Sept 2019

Worku A, Lemenih M, Fetene M, Teketay D (2011) Socio-economic importance of gum and resin resources in the dry woodlands of Borana, southern Ethiopia. Forests Trees Liveli 20:137-156

\section{Publisher's Note}

Springer Nature remains neutral with regard to jurisdictional claims in published maps and institutional affiliations.

\section{Submit your manuscript to a SpringerOpen ${ }^{\circ}$ journal and benefit from:}

- Convenient online submission

- Rigorous peer review

- Open access: articles freely available online

- High visibility within the field

- Retaining the copyright to your article

Submit your next manuscript at $>$ springeropen.com 